\title{
Biological aspects and feeding behavior of cotton aphid in watermelon cultivars submitted to silicon application
}

\section{Aspectos biológicos e comportamento alimentar do pulgão-do-algodoeiro em cultivares de melancia submetidas à aplicação de silício}

\author{
Rosane Rodrigues da Costa Pereira 1* (1) (https://orcid.org/0000-0002-3375-4322) \\ Roneres Deniz Barbosa2 (1) (https://orcid.org/0000-0003-3325-8625) \\ Luciana Diniz Ferreira 2 (1) (https://orcid.org/0000-0002-8693-6058) \\ Douglas Marcelo Pinheiro da Silva² (1) (https://orcid.org/0000-0003-3422-1576) \\ Ronelza Rodrigues da Costa Zaché 3 (1) (https://orcid.org/0000-0001-5932-3566) \\ Carlos Eduardo Pereira' (1) (https://orcid.org/0000-0002-8355-1128)
}

\begin{abstract}
This research aimed to evaluate the biological aspects and the feeding behavior of Aphis gossypii in watermelon cultivars submitted to silicon application. The experiment was conducted at the Institute of Education, Agriculture and Environment of the Federal University of Amazonas, Humaitá, Brazil. The experimental design was completely randomized in a $2 \times 3$ factorial (with and without silicon; cultivars Crimson Sweet, Fairfax and Charleston), with ten replications. The application of silicic acid (1\%) was carried out directly on the substrate using dose equivalent to 1 ton $\mathrm{SiO}_{2} \cdot \mathrm{ha}^{-1}, 25$ days after sowing. The rearing of aphids was kept in cucumber plants, cultivar Caipira. Insect biology tests were conducted to evaluate the duration of the prereproductive, reproductive and postreproductive periods, longevity, number of nymphs, and feeding behavior using the honeydew secretion technique. Analysis of variance was performed using the statistical program SISVAR and the means were compared by the F and Scott-Knott test $(\mathrm{p} \leq 0.05)$. The silicon application to watermelon plants affects the reproduction and feeding of $A$. gossypii. The watermelon plants cultivar Crimson Sweet treated with silicon has high resistance to feeding by $A$. gossypii.
\end{abstract}

KEYWORDS: silicon acid; aphids; cucurbitaceous; constitutive resistance; Aphis gossypii.
RESUMO: Nesta pesquisa objetivou-se avaliar os aspectos biológicos e o comportamento alimentar de Aphis gossypii em cultivares de melancia submetidas à aplicação de silício. $\mathrm{O}$ experimento foi conduzido no Instituto de Educação, Agricultura e Ambiente da Universidade Federal do Amazonas, Humaitá, Brasil. Utilizaram-se o delineamento experimental inteiramente ao acaso e o esquema fatorial $2 \times 3$ (sem silício e com silício; cultivares Crimson Sweet, Fairfax e Charleston), com dez repetiçóes. A aplicação do ácido silícico (1\%) foi realizada diretamente no substrato, com dose equivalente a 1 ton $\mathrm{SiO}_{2} \cdot \mathrm{ha}^{-1}, 25$ dias após a semeadura. Os pulgóes da criação foram mantidos em plantas de pepino, cultivar Caipira. Foram conduzidos ensaios de biologia do inseto para avaliação da duração dos períodos pré-reprodutivo, reprodutivo e pós-reprodutivo, longevidade, número de ninfas e comportamento alimentar por meio da técnica de secreção de honeydew. Realizou-se a análise de variância dos dados utilizando-se o programa estatístico SISVAR e as médias foram comparadas pelo teste de F e Scott-Knott $(\mathrm{p} \leq 0,05)$. A aplicaçáo de silício em plantas de melancia afeta a reproduçáo e a alimentaçáo de $A$. gossypii. Plantas de melancia do cultivar Crimson Sweet tratadas com silício apresentam alta resistência à alimentaçáo por $A$. gossypii.

PALAVRAS-CHAVE: ácido silícico; afídeos; cucurbitácea; resistência constitutiva; Aphis gossypii. 


\section{INTRODUCTION}

Watermelon, Citrullus lanatus (Thunb.) Matsum \& Nakai, is a Cucurbitaceae with a worldwide production of 118 million tons, and Brazil is the world's fifth largest producer with 2.240 million tons (FAO, 2018). In the state of Amazonas, Brazil, watermelon planted area covers 3068 hectares, involves 8415 family farmers (IBGE, 2017), and is a crop of great importance, especially for small farmers.

Pest insects can infest watermelon plantations and reduce production and fruit quality. The aphid Aphis gossypii Glover (Hemiptera: Aphididae) is one of the main pests of this crop (SILVA et al., 2002). This species can feed on different cultures and is widely distributed around the world (BLACKMAN; EASTOP, 1984). It sucks the plant sap, causes deformities in the leaves and branches, reduces the plant photosynthetic capacity, as well as facilitates transmission of viruses from the genus Potyvirus (PINTO et al., 2008).

Application of chemical products is still the most used method to control $A$. gossypii in watermelon plants. However, there are many reasons to invest in alternative control methods to replace or decrease the use of insecticides, such as development of pest resistance to the active principle (PALUMBO et al., 2001) and consequently increased dosage and applications, the high cost of chemical control and persistence on vegetal products and ecotoxicological problems. Thus, alternative methods of pest control are increasingly being studied.

The plants resistance to insect attack can collaborate to maintain the aphid population density below the level of economic damage, consequently, reducing losses in production. Therefore, the use of variety resistant to aphids can be a good alternative. The induced resistance is another promising method in the management of $A$. gossypii. This method causes changes in the quality and quantity of secondary substances and nutrients, as well as cellular and histological changes which affect the behavior, physiology, biology and ecology of insects and pathogens (PANIZZI; PARRA, 1991).

In this way, the constitutive resistance of watermelon cultivars and the induction of resistance to pests through silicate fertilization can contribute to the integrated management of $A$. gossypii in watermelon culture, alone or synergistically. Thus, the objective of this research was to evaluate the biological aspects and feeding behavior of $A$. gossypii in watermelon cultivars submitted to silicon application.

\section{MATERIAL AND METHODS}

The experiment was carried out in a greenhouse and airconditioned room at the Plant Health Laboratory in the
Institute of Education, Agriculture and Environment (IEAA) of the Federal University of Amazonas (UFAM), Humaitá, Amazonas, Brazil. The experimental design was completely randomized in a factorial scheme $2 \times 3$ (with and without silicon; cultivars Crimson Sweet, Fairfax and Charleston), with ten replications.

Four watermelon seeds were sown in each pot containing $10 \mathrm{~kg}$ of substrate soil/cattle manure at the ratio 3:1. The pots were placed on a bench in greenhouse. Twenty days after sowing, thinning was conducted leaving only one plant in each pot. The application of silicic acid (1\%) was carried out directly on the substrate, with a dose equivalent to 1 ton $\mathrm{SiO}_{2} \cdot$ ha $^{-1}, 25$ days after sowing. Each pot was used as a replication.

The aphids A. gossypii were collected in commercial watermelon crops next to Humaitá, Amazonas, Brazil, and were kept in climatized chambers at $25 \pm 2{ }^{\circ} \mathrm{C}$ and photophase of $12 \mathrm{~h}$. Cucumber plants, cultivar Caipira, were grown in pots with $5 \mathrm{~kg}$ of substrate, in greenhouse, to provide food for creation of $A$. gossypii.

Aphids remained in leaf sections of cucumber with $8 \mathrm{~cm}$ diameter, washed and immersed in hypochlorite solution (1\%) for $5 \mathrm{~min}$. These leaves were fixed in Petri dishes using agar-water $(1 \%)$ and closed with voile fabric and rubber ties. When the leaves turned yellow, they were replaced.

\section{Biological aspects of $A$. gossypii}

A cage of transparent material of $0.5 \mathrm{~cm}$ height and $0.8 \mathrm{~cm}$ diameter was fixed in each plant with metal clip, five days after the silicon application. Two adult females of $A$. gossypii beginning reproductive period were kept in each cage for $24 \mathrm{~h}$. After this period, adult females were removed, and a newborn nymph was left. The duration of the prereproductive, reproductive and postreproductive periods, longevity and number of nymphs were evaluated. During the reproductive period, the nymphs were counted and removed from the cages daily.

\section{Feeding behavior of $A$. gossypii}

This test was conducted 10 days after silicon application in laboratory at $25 \pm 4^{\circ} \mathrm{C}$. A plastic cylinder $12 \mathrm{~cm}$ in diameter and $2.5 \mathrm{~cm}$ wide was covered with a filter paper strip impregnated with solution of $0.3 \mathrm{~g}$ of ninhydrin, $3 \mathrm{~mL}$ of glacial acetic acid and $10 \mathrm{~mL}$ of $\mathrm{n}$-butanol. This cylinder was fixed on an analog clock with $12 \mathrm{~h}$ rotation supported by an iron rod. An aphid kept without feeding for $1 \mathrm{~h}$ before the start of the test was placed on abaxial side of watermelon leaf, for each treatment and replication, that was placed $1 \mathrm{~cm}$ above the filter paper strip. The droplets of honeydew, secreted by the insects, colored the paper strip of purple, due to the ninhydrin. The number of droplets of honeydew, the time for the first droplet and the time for the last droplet were evaluated. 


\section{Statistic}

Analysis of variance was performed using the statistical program Sisvar, version 4.0 (FERREIRA, 2014). The means of the silicon treatment were compared using the F-test $(\mathrm{p} \leq 0.05)$ and the cultivars using the test of SCOTT; KNOTT (1974) at the level of $5 \%$ probability. The transformation $\sqrt{ }(X+0.5)$ was made for the number of honeydew droplets.

\section{RESULTS AND DISCUSSION}

\section{Biology of $A$. gossypii}

It was found, through analysis of variance, significant effects on the number of nymphs for the application of silicon, however no significant differences were observed for the other sources of variation. There were no significant differences for longevity and for prereproductive, reproductive and postreproductive periods for the sources of variation studied (Table 1).

The number of nymphs in the watermelon plants was higher when silicon was not applied (control) compared to the plants treated with this element, independent of cultivar effect (Table 2). Similarly, it was observed that the number of nymphs of Schizaphis graminium (Rondani) was higher when not treated with silicon in sorghum plants (CARVALHO et al., 1999; COSTA; MORAES, 2006) and in wheat plants (BASAGLI et al., 2003). ALCANTRA et al. (2019) observed no effects of silicon application on any biological parameters of $A$. gossypii feeding plants of cotton genotypes with silicon.

GOUSSAIN et al. (2005) observed a lower rate of sap intake in individuals of $S$. graminium when they are feeding on wheat plants fertilized with silicon. Thus, the fertility of aphids can be reduced due to energetic substances deficiency in the organism. The reproductive potential of aphids is influenced by the host plant (physiological state, morphology and natural resistance) and by climatic conditions, such as temperature and other factors (KOCOUREK et al., 1994; BETHKE et al., 1998).

COSTA; MORAES (2006) found that the prereproductive and reproductive periods of $S$. graminium were not affected by the application of silicon in wheat plants. Also, GOUSSAIN et al. (2005) found no influence on the prereproductive and postreproductive periods of this same aphid. GOMES et al. (2005) did not observe effect of Si in the prereproductive, reproductive periods and longevity of Myzus persicae (Sulzer) (Hemiptera: Aphididae) in potato plants. In addition, NERI et al. (2009) found that the prereproductive and postreproductive periods of the caterpillar Spodoptera frugiperda (J.E. Smith) (Lepidoptera: Noctuidae) feeding corn plants did not differ when plants were fertilized with silicon or not treated.

MICHELOTTO; BUSOLI (2003) found that the average longevity, reproductive and postreproductive period of A. gossypii were 14, 6 and 21 days, respectively, in different cotton cultivars. ALCANTRA et al. (2019), studying these same parameters and insect species in other cotton cultivars, found values of 12, 1.2 and 13 days. For the three watermelon cultivars evaluated in the present study the periods of 22, 0.65 and 27 days were observed for these parameters for $A$. gossypii.

\section{Feeding behavior of $A$. gossypii}

Table 3 shows the analysis of variance and significant effects are observed for the number of droplets of honeydew when

Table 1. Mean squares of the number of nymphs (NN), prereproductive (PRE), reproductive (RP) and postreproductive (POS) period and longevity (LON) of $A$. gossypii in different watermelon cultivars submitted to the silicon application.

\begin{tabular}{lccccccc} 
& & & \multicolumn{4}{c}{ Mean Squares } \\
\cline { 5 - 7 } & SV & NN & PRE & RP & POS & LON \\
\hline Silicon & 1 & $6080.267^{* *}$ & $0.067^{\text {ns }}$ & $117.600^{\text {ns }}$ & $0.817^{\text {ns }}$ & $112.067^{\text {ns }}$ \\
\hline Cultivars & 2 & $674.817^{\text {ns }}$ & $0.117^{\text {ns }}$ & $17.150^{\text {ns }}$ & $1.850^{\text {ns }}$ & $17.717^{\text {ns }}$ \\
\hline Silicon $\times$ cultivars & 2 & $1205.117^{\text {ns }}$ & $0.117^{\text {ns }}$ & $35.150^{\text {ns }}$ & $0.317^{\text {ns }}$ & $48.017^{\text {ns }}$ \\
\hline Error & 54 & 581.552 & 0.063 & 32.663 & 0.639 & 41.174 \\
\hline CV (\%) & - & 28.16 & 5.05 & 25.98 & 122.97 & 23.31 \\
\hline
\end{tabular}

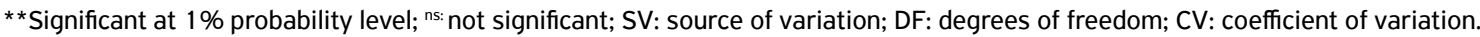

Table 2. Mean values of the number of nymphs (NN), prereproductive (PRE), reproductive (RP) and postreproductive (POS) periods and longevity (LON) of $A$. gossypii in watermelon plants submitted to silicon application in greenhouse.

\begin{tabular}{lccccc} 
Silicon & NN & PRE & RP & POS & LON \\
Without Si & $95.70 \pm 3.51 \mathrm{a}$ & $5.0 \pm 0.05 \mathrm{a}$ & $23.4 \pm 0.62 \mathrm{a}$ & $0.53 \pm 0.13 \mathrm{a}$ & $28.93 \pm 0.66 \mathrm{a}$ \\
\hline With $\mathrm{Si}$ & $75.57 \pm 5.30 \mathrm{~b}$ & $4.9 \pm 0.05 \mathrm{a}$ & $20.6 \pm 1.33 \mathrm{a}$ & $0.77 \pm 0.16 \mathrm{a}$ & $26.13 \pm 1.50 \mathrm{a}$ \\
\hline
\end{tabular}

Means followed by the same vertical letter are not significantly different by the F-test $(p \leq 0.05)$. 
Table 3. Mean squares of the number of droplets (NG), time to first droplet (TFD) and time to last droplet (TLD) of $A$. gossypii honeydew in different watermelon cultivars subjected to the silicon application.

\begin{tabular}{|c|c|c|c|c|}
\hline \multirow{2}{*}{ sV } & \multirow{2}{*}{ DF } & \multicolumn{3}{|c|}{ Mean squares } \\
\hline & & NG & TFD & TLD \\
\hline Silicon & 1 & $10.548^{* *}$ & 41.631 ** & $147.320^{* *}$ \\
\hline Cultivars & 2 & $0.505^{\mathrm{ns}}$ & $105.555^{* *}$ & $60.749 * *$ \\
\hline Silicon $\times$ cultivars & 2 & $0.493^{n s}$ & $75.224^{* *}$ & $94.225^{* *}$ \\
\hline Error & 24 & 0.194 & 0.376 & 7.140 \\
\hline CV (\%) & - & - & 25.12 & 33.74 \\
\hline
\end{tabular}

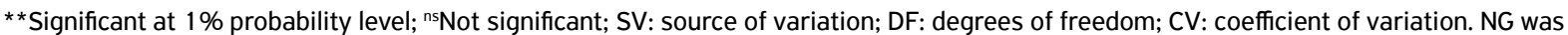
transformed into $\sqrt{ }(X+0.5)$.

silicon was applied, independent of the cultivar effect. It also shows significant interaction between cultivars and silicon application to time for first droplet and the time for last droplet.

According to MITTLER (1958), the rate of sap ingested by the insect can be measured by the secretion of honeydew. So, when silicon was applied, independent of the cultivar, insects secreted less than a quarter of the number of droplets compared to plants not treated with Si (Table 4). Probably, the insects in plants that received silicon application had difficulties in feeding and reduced the volume of secretion due to the mechanical barrier formed in the plants by $\mathrm{Si}$. In addition to this barrier, silicon can induce an increase in the production of compounds with harmful effects on the insect (MARSCHNER, 1995). PEREIRA et al. (2010) found that the Si applied to wheat plants affected the production of droplets of honeydew from Schizaphis graminum.

Aphids did not feed on the plants of the cultivar Crimson Sweet when they received silicon application; there was no production of droplets, indicating a possible high-grade antixenosis (Table 4). This type of resistance is related to plant secondary metabolism and comes from physical, morphological and chemical changes (LARA, 1991). Silicon may have induced the plant to produce defense compounds and/or changed the thickness of the plant epidermis. According to AGARIE et al. (1998), the cell wall becomes thick due to deposition of silicon in the epidermal cells. In addition, its application probably acted synergistically to the cultivar constitutive resistance.

The time to produce the first droplet in the cultivar Fairfax treated with silicon was $10.54 \mathrm{~h}$; aphids showed difficulty to start feeding on these plants. On the other hand, there was no significant difference between cultivars when silicon was not applied.

There was no aphid feeding on the cultivar Crimson Sweet when silicon was applied. However, when silicon was not applied, the insects started to feed less than $1 \mathrm{~h}$ after the start of the test. There was also difference for the cultivar Fairfax between treatments with and without application of silicon. The treatment of plants with silicon increased the time for the first droplet by almost $9 \mathrm{~h}$, indicating difficulty in insects feeding in this treatment. For the cultivar Charleston, there was no significant response to the silicon application in relation to the time for the first droplet.
Table 4. Time, in hours, for secretion of the first droplet and number of droplets of honeydew of $A$. gossypii in watermelon cultivars submitted or not to the silicon application.

\begin{tabular}{lcc}
\multirow{2}{*}{ Cultivars } & \multicolumn{2}{c}{ Time for the first droplet (hours) } \\
\cline { 2 - 3 } Crimson Sweet & With silicon & Without silicon \\
\hline Fairfax & $0.00 \pm 0.00 \mathrm{bB}^{*}$ & $0.95 \pm 0.42 \mathrm{aA}$ \\
\hline Charleston & $10.54 \pm 0.25 \mathrm{aA}$ & $1.85 \pm 0.30 \mathrm{aB}$ \\
\hline Silicon & $0.32 \pm 0.15 \mathrm{bA}$ & $1.00 \pm 0.31 \mathrm{aA}$ \\
\hline Without silicon & Number of droplets \\
\hline With silicon & $5.40 \pm 0.41 \mathrm{~B}$ \\
\hline
\end{tabular}

Means followed by the same lowercase letters comparing cultivars and capital letters comparing silicon do not differ statistically by Scott-Knott and F-test, respectively $(p \leq 0.05)$. *There was no feeding by $A$. gossypii.

These results corroborate with GOUSSAIN et al. (2005), who found that secretion of honeydew droplets from S. graminum was reduced when these aphids feed with wheat plants treated with Si. This reduction and the increase of time to start feeding indicates that silicon may be producing a barrier in these plants, causing a decrease in feeding. COSTA et al. (2011) found that the silicon application combined or not with imidacloprid reduced the feeding time of $S$. graminum in wheat plants. According to GOUSSAIN et al. (2002), silicon accumulates in plants and provide a mechanical barrier to pest attack and/or induce the synthesis of phenolic compounds, which decrease palatability to pest insects.

The time for the secretion of the last droplet showed significant difference between cultivars only when the plants were treated with silicon (Table 5). In this condition, there was no feeding of the insects for the cultivar Crimson Sweet, while the cultivar Fairfax showed a longer time for the secretion of the last droplet.

For the cultivars Crimson Sweet and Charleston, the application of silicon in the honeydew test reduced the time for secretion of the last droplet compared to the untreated plants of these cultivars; thus, silicon showed a positive interaction with these cultivars. In integrated pest management, it is recommended to combine control methods to maintain crop 
Table 5. Time, in hours, for honeydew last droplet secretion from A. gossypii in watermelon cultivars submitted to the silicon application.

\begin{tabular}{lcr}
\multirow{2}{*}{ Cultivars } & \multicolumn{2}{c}{ Time for honeydew last droplet (hours) } \\
\cline { 2 - 3 } & \multicolumn{1}{c}{ With silicon } & \multicolumn{1}{c}{ Without silicon } \\
\hline Crimson Sweet & $0.00 \pm 0.00 \mathrm{cB} *$ & $10.39 \pm 0.63 \mathrm{aA}$ \\
\hline Fairfax & $10.93 \pm 0.34 \mathrm{aA}$ & $9.06 \pm 1.25 \mathrm{aA}$ \\
\hline Charleston & $6.18 \pm 2.54 \mathrm{bB}$ & $10.96 \pm 0.23 \mathrm{aA}$
\end{tabular}

Means followed by the same lowercase letter in the column and capital letters in the rows are not different statistically by Scott-Knott and $F$ test, respectively $(\mathrm{p} \leq 0.05)$. *There was no feeding by A. gossypii. health. Thus, associating constitutive and induced resistance may be a good tactic for the management of $A$. gossypii in watermelon.

\section{ACKNOWLED GEMENTS: Not applicable}

FUNDING: Conselho Nacional de Desenvolvimento Científico e Tecnológico (Grant number 482220/2011-2).

CONFLICTS OF INTEREST: All authors declare that they have no conflict of interest.

ETHICAL APPROVAL: Not applicable.

AVAILABILITY OF DATA AND MATERIAL: The datasets generated and/or analyzed during the current study are available from the corresponding author on reasonable request.

AUTHORS' CONTRIBUTIONS: Conceptualization: Pereira, R.R.C.; Pereira, C.E.; Zaché, R.R.C. Funding acquisition: Pereira, R.R.C. Investigation: Barbosa, R.D.; Ferreira, L.D.; Silva, D.M.P. Methodology: Pereira, R.R.C.; Zaché, R.R.C.; Pereira, C.E. Project administration: Pereira, R.R.C. Supervision: Pereira, R.R.C.; Silva, D.M.P. Writing - original draft: Pereira, R.R.C.; Zaché, R.R.C. Writing - review \& editing: Pereira, R.R.C.; Pereira, C.E.

\section{REFERENCES}

AGARIE, S.; HANAOKA, N.; UENO, O.; MIYAZAKI, A.; KUBOTA, F.; AGATA, W.; KAUFMAN, P.B. Effects of silicon on tolerance to water deficit and heat stress in rice plants (Oryza sativa L.), monitored by electrolyte leakage. Plant Prodution Science, Tokyo, v. 1, n.2, p.96-103, 1998. https://doi.org/10.1626/pps.1.96

ALCANTRA, E.; MORAES, J.C.; AUAD, A.M.; SILVA, A.A.; ALVARENGA, R. Resistência induzida ao pulgão-do-algodoeiro em cultivares de algodão colorido. Revista de Ciências Agrárias, Lisboa, v.42, n.2, p.483-491, 2019. https://doi. org/10.19084/rca.17183

BASAGLI, M.A.B.; MORAES, J.C.; CARVALHO, G.A.; ECOLE; C.C.; GONÇALVES-GERVÁSIO, R.C.R. Effect of sodium silicate on the resistance of wheat plants to green-aphids Schizaphis graminum (Rond.) (Hemiptera: Aphididae). Neotropical Entomology, Londrina, v.32, n.4, p.659-663, 2003. https://doi.org/10.1590/ S1519-566X2003000400017

BETHKE, J.A.; REDAK, R.A.; SCHUCH, U.K. Melon aphid performance on chrysanthemum as mediated by cultivar and differential levels of fertilization and irrigation. Entomologia Experimentalis et Applicata, Wageningen, v.88, n.1, p.41-47, 1998. https://doi. org/10.1046/j.1570-7458.1998.00344.x

BLACKMAN, R.L.; EASTOP, V.P. Aphids on the word's crops: an identification guide. New York: John Wiley \& Sons, 1984. 466p.
CARVALHO, S.P.; MORAES, J.C.; CARVALHO J.G. Efeito do silício na resistência do sorgo (Sorghum bicolor) ao pulgão-verde Shizaphis graminium (Rond.) (Homoptera: Aphididade). Anais da Sociedade Entomológica do Brasil, Londrina, v.28, n.3, p.505-510, 1999. https://doi.org/10.1590/S0301-80591999000300017

COSTA, R.R.; MORAES, J.C. Efeitos do ácido silícico e do acibenzolar-S-methyl sobre Schizaphis graminium (Rondani) (Hemiptera: Aphididae) em plantas de trigo. Neotropical Entomology, Londrina, v.35, n.6, p.834-839, 2006. https:// doi.org/10.1590/S1519-566X2006000600018

COSTA, R.R.; MORAES, J.C.; DACOSTA, R.R. Feeding behaviour of the green bug Schizaphis graminum on wheat plants treated with imidacloprid and/or silicon. Journal Applied Entomology, Goettingen, v.135, n.1-2, p.115-120, 2011 . https://doi. org/10.1111/j.1439-0418.2010.01526.x

Food and Agriculture Organization of the United Nations (FAO). Countries by commodity. 2018. Available from: http://www.fao. org/faostat/en/\#rankings/countries_by_commodity. Access on: 28 Feb. 2020.

FERREIRA, D.F. Sisvar: A guide for its bootstrap procedures in multiple comparisons. Ciência e Agrotecnologia, Lavras, v.38, n.2, p.109-112, 2014 . https://doi.org/10.1590/ S1413-70542014000200001 
GOMES, F.B.; MORAES, J.C.; SANTOS, C.D.; GOUSSAIN, M.M. Resistance induction in wheat plants by silicon and aphids. Scientia Agricola, Piracicaba, v.62, n.6, p.547-551. 2005. https://doi. org/10.1590/SO103-90162005000600006

GOUSSAIN, M.M.; MORAES, J.C.; CARVALHO, J.G.; NOGUEIRA, N.L.; ROSSI, M.L. Efeito da aplicação de silício em plantas de milho no desenvolvimento biológico da lagarta-do-cartucho Spodoptera frugiperda (J. E. Smith) (Lepidoptera: Noctuidae). Neotropical Entomology, Londrina, v.31, n.2, p.305-310, 2002. https://doi. org/10.1590/S1519-566X2002000200019

GOUSSAIN, M.M.; PRADO, E.; MORAES, J.C. Effect of silicon applied to wheat plants on the biology and probing behaviour of the greenbug Schizaphis graminum (Rond.) (Hemiptera: Aphididae). Neotropical Entomology, Londrina, v.34, n.5, p.807-813, 2005. https://doi.org/10.1590/S1519-566X2005000500013

INSTITUTO BRASILEIRO DE GEOGRAFIA E ESTATÍSTICA (IBGE) Censo Agropecuário. 2017. Available from: https://cidades.ibge. gov.br/brasil/am/pesquisa/24/76693. Access on: 28 Feb. 2020.

KOCOUREK, F.; HAVELKA, J.; BERÁNKOVÁ, J.; JAROŜIK, V. Effect of temperature on development rate and intrinsic rate of increase of Aphis gossypii reared on greenhouse cucumbers. Entomologia Experimentalis et Applicata, Wageningen, v.7 1, n. 1 , p.59-64, 1994. https://doi.org/10.1111/j.1570-7458.1994. tb01769.x

LARA, F.M. Princípios de resistência de plantas a insetos. São Paulo: Ícone, 1991, 336p.

MARSCHNER, H. Mineral nutrition of higher plants. Cambridge: Academic Press, 1995. 889p.

MICHELOTTO, M.D.; BUSOLI, A.C. Aspectos biológicos de Aphis gossypii Glover, 1877 (Hemiptera: Aphididae) em três cultivares de algodoeiro e em três espécies de plantas daninhas. Ciência Rural, Santa Maria, v.33, n.6, p.999-1004, 2003. https://doi. org/10.1590/SO103-84782003000600002
MITTLER, T.E. Studies on the feeding and nutrition of Tuberolachnus salignus (Gmelin) (Homoptera: Aphididae) II: the nitrogen and sugar composition of ingested phloem sap and excreted honeydew. Journal of Experimental Biology, Oxford, v.35, n. 1, p.74-84, 1958.

NERI, D.K.P.; GOMES, F.B.; MORAES, J.C.; GÓES, G.B.; MARROCOS, S.T.P. Influência do silício na suscetibilidade de Spodoptera frugiperda (J.E. Smith) (Lepidoptera: Noctuidae) ao inseticida lufenuron e no desenvolvimento de plantas de milho. Ciência Rural, Santa Maria, v.39, n.6, p.1633-1638, 2009. https://doi. org/10.1590/SO103-84782009005000111

PALUMBO, J.C.; HOROWITZ, A.R.; PRABHAKER, N. Insecticidal control and resistance management for Bemisia tabaci. Crop Protection, Lincoln, v.20, n.9, p.739-76, 2001. https://doi. org/10.1016/SO261-2194(01)00117-X

PANIZZI, A.R.; PARRA, J.R.P. Ecologia nutricional de insetos e suas implicações no manejo de pragas. São Paulo: Manole, 1991. 359p.

PEREIRA, R.R.C.; MORAES, J.C.; PRADO, E.; DACOSTA, R.R. Resistance inducing agents on the biology and probing behaviour of the greenbug in wheat. Scientia Agricola, Piracicaba, v.67, n.4, p.430-434, 2010. https://doi.org/10.1590/S0103-90162010000400009

PINTO, Z.V.; REZENDE, J.A.M.; YUKI, V.A.; PIEDADE, S.M.S. Ability of Aphis gossypii and Myzus persicae to transmit cucumber mosaic virus in single and mixed infection with two potyviruses to zucchini squash. Summa Phytopathologica, Botucatu, v.34, n.2, p.183-185, 2008. https://doi.org/10.1590/SO100-54052008000200016

SCOTT, A.J.; KNOTT, M. Cluster-analysis method for grouping means in analysis of variance. Biometrics, Washington, v.30, n.3, p.507-512, 1974. https://doi.org/10.2307/2529204

SILVA, P.R.V.P.; NASCIMENTO, E.P.; DIAS, M.R.N. Insetos de importância econômica para a cultura da melancia (Comunicado Técnico 10). Boa Vista: Embrapa Roraima, 2002, 16p. Available from: https:// ainfo.cnptia.embrapa.br/digital/bitstream/item/175987/1/ Cot0102002-melancia-paulo.pdf. Access on: 28 Feb. 2020. 